\title{
Perkembangan Kemandirian dan Keterampilan Sosial Anak Usia 5-6 Tahun dalam Pengasuhan Dual Career Family
}

\author{
Chasya Aghniarrahmah ${ }^{\circledR}{ }^{\bowtie}$ Lara Fridani $^{2}$, Asep Supena ${ }^{3}$ \\ Pendidikan Anak Usia Dini, Universitas Negeri Jakarta, Indonesia $(1,2,3)$ \\ DOI: $\underline{10.31004 / \text { obsesi.v6i1.1319 }}$
}

\begin{abstract}
Abstrak
Kemandirian dan keterampilan sosial merupakan dua hal fundamental yang harus distimulus sejak usia dini yang dipengaruhi oleh pengasuhan keluarga. Penelitian ini bertujuan untuk mengkaji bentuk-bentuk kemandirian dan keterampilan sosial yang muncul pada anak uisa 5-6 tahun yang memiliki kedua orang tua bekerja di Jakarta. Penelitian menggunakan metode kualitatif jenis studi kasus tipe single case study. Subjek penelitian berinisial K, usia 6 tahun memiliki kedua orang tua bekerja. Subjek dan informan dipilih melalui teknik purposive sampling. Data pada penelitian diperoleh melalui pengamatan, wawancara yang mendalam dan pengumpulan dokumentasi. Teknik analisis data menggunakan model Miles and Hubberman. Hasil penelitian menunjukkan adanya perbedaan antara kemandirian saat anak di rumah dan di sekolah, keterampilan sosial anak belum berkembang sesuai dengan tahapan usianya, adanya pelimpahan pengasuhan yang dilakukan orang tua kepada pihak ketiga yaitu nenek dan pengasuh, serta adanya perbedaan penerapan pola pengasuhan yang diberikan Kata Kunci: anak usia dini, dual career family, kemandirian, keterampilan sosial, pola asuh.
\end{abstract}

\begin{abstract}
Independence and social skills are two fundamental things in individual life that must be stimulated from an early age. This is inseparable from the parenting style given by the parents. This study aims to analyze the forms of independence and social skills that have emerged of aged 5 to 6 years old children in a dual career family. Informants in this study were four people based on purposive sampling. The research subjects had the initial of $K$, a 6 years old child whose the parents are working who choosen by purposive sampling. This study employs a qualitative method with single case study. The data in this study were obtained through an observation, in-depth interviews and documentation collections. The technical data analysis used Miles and Hubberman models. The results found a difference in children's independence when they are at home and in school, their social skills have not developed based on the stages of their age, the presence of the negligence of parenting of parents to the third parties namely grandmother and caregivers, and the difference in the patternal of parenting carried out by the parents and grandmothers. The implication of this study is the need for an active involvement and understanding of parents in selecting parenting style that by considering the age stages and the needs of children.
\end{abstract}

Keywords:early childhood education, dual career family, independence, parenting styles, social skills.

Copyright (c) 2021 Chasya Aghniarrahmah, Lara Fridani, Asep Supena

$\triangle$ Corresponding author :

Email Address: ChasyaAghniarrahmah_paud17s2@mahasiswa.unj.ac.id (Jakarta, Indonesia)

Received 23 April 2021, Accepted 22 May 2021, Published 31 May 2021 


\section{PENDAHULUAN}

Anak usia dini memiliki tugas yang harus dicapai dalam bidang pembiasaan diri dan pengembangan kemampuan dasar berdasarkan PERMENDIKNAS No. 146 Kurikulum 2013 (Hanifah, 2020). Pada bidang pembiasaan diri terdapat dua aspek yang penting untuk dikembangkan yaitu aspek sosial dan emosional yang di dalamnya meliputi keterampilan sosial dan aspek kemandirian. Hal ini penting dilakukan karena anak tumbuh dan berkembang secara pesat pada masa usia dini. Berdasarkan pernyatan NAEYC, usia dini berada pada masa anak baru dilahirkan sampai usia delapan tahun (Yolanda, 2020). Semua hal yang anak pelajari pada 8 tahun pertama akan berdampak pada perkembangan kehidupan sepanjang hayatnya melalui proses interaksi dengan lingkungan (Kuhn, 2017). Seperti yang dikatakan Montessori dalam teori absorbent mind, pada dasarnya anak akan menyerap apapun yang diterima dari lingkungan karena pada masa ini 80 persen otak anak berkembang secara pesat bagaikan sebuah sponge (Zhang, 2019). Oleh sebab itu, anak memerlukan stimulus dari lingkungan terutama keluarga melalui pembiasaan yang positif kepada anak agar dapat tumbuh menjadi pribadi yang mandiri dan dapat diterima dengan baik dalam lingkungan sosial.

Sejalan dengan teori ekologi dari Brofenbrenner yang secara garis besar menjelaskan bahwa perkembangan sepanjang hayat manusia dipengaruhi oleh lingkungan (chronosistem) tempat seseorang hidup (Santrock, 2015). Sejalan dengan hal tersebut, teori sosiokultural dari Vygotsky juga memperkuat alasan bahwa lingkungan memainkan peran penting dalam perkembangan anak (Papalia \& Feldman, 2014). Anak belajar dan menemukan hal-hal baru melalui interaksi dengan lingkungan. Interaksi juga membuat anak memahami segala proses kehidupan dan mendorong anak untuk terus belajar dari pengalaman. Berdasarkan pernyataan di atas, salah satu dari tugas perkembangan yang penting untuk dicapai oleh anak berkaitan dengan lingkungan sosial adalah ketika anak mampu berinteraksi dengan baik dalam lingkungan atau lebih dikenal dengan istilah keterampilan sosial. Keterampilan sosial yang diperoleh pada masa kanak-kanak awal saat bersosialisasi berperan dalam menentukan hubungan dengan orang lain karena pada masa ini anak-anak diperkenalkan dengan berbagai macam hubungan serta keterkaitan dengan orang-orang baru (Ogelman, Güngör, Körükçü, Sarkaya \& Hatice, 2016).

Sebagai individu yang diharapkan memiliki keterampilan sosial yang baik serta dapat diterima di dalam kehidupan masyarakat, anak dituntut mandiri. Kemandirian penting untuk ditanamkan karena dapat mendorong anak agar bertanggung jawab atas pilihan sendiri, menjadi disiplin serta lebih dapat mengenal dirinya sendiri. Sikap tersebut bertujuan agar anak diharapkan mampu mengontrol perilaku sesuai dengan aturan-aturan yang berlaku dalam kehidupan masyarakat (Côté-lecaldare, Joussemet, Dufour, \& Sarah, 2016). Kemandirian akan berkembang dengan baik apabila anak mendapatkan dukungan penuh dari keluarga dan lingkungan sekitarnya. Contoh sederhana sebagai wujud anak mandiri adalah saat bermain, anak bertanggung jawab untuk selalu menjaga alat permainan agar tidak rusak serta berinisiatif untuk membereskan mainan ketika sudah selesai. Contoh lain terlihat ketika anak sudah terbiasa menyikat gigi saat bangun dan sebelum tidur tanpa diminta. Anak sudah mampu melaksanakan toilet training sehingga tidak perlu ditemani lagi saat harus ke toilet. Kemandirian tidak dapat muncul sendiri dalam diri anak. Kemandirian akan berkembang dengan baik apabila anak mendapatkan dukungan penuh dari keluarga serta lingkungan untuk mendorong agar anak menjadi pribadi yang lebih mandiri.

Perkembangan kemandirian dan keterampilan sosial pada anak tidak terlepas dari peran keluarga. Keluarga menjadi support system utama dalam perkembangan dan kehidupan anak yang siap untuk mendukung serta memberikan dorongan positif berupa stimulus agar anak tumbuh dan berkembang dengan optimal (Green, 2019). Berdasarkan hal tersebut, keluarga merupakan sebuah unit terpenting dalam kehidupan seseorang karena keluarga merupakan lingkungan sosial utama dan terdekat pada anak. Istilah keluarga sendiri berasal dari kata "family" dan "familier" yang memiliki arti terkenal. Dalam tatanan budaya 
masyarakat yang berkembang, idealnya dalam sebuah keluarga ayah berperan sebagai pencari nafkah, sementara itu ibu bertugas sebagai seseorang yang mengasuh anak di rumah. Namun, beberapa dekade terakhir banyak ibu yang memilih untuk menjadi wanita karir.

Data terbaru menunjukkan bahwa enam dari sepuluh perempuan dewasa di seluruh dunia merupakan ibu yang bekerja secara full time (Wittenberg, 2020). Selanjutnya, Badan Pusat Statistik memberikan data adanya peningkatan jumlah tenaga pekerja perempuan Indonesia yang berusia antara 25 tahun sampai 35 tahun dalam kurun waktu 3 tahun selama 2015 sampai 2017 sebanyak 1,88 persen (Hesti, 2017). Sementara itu, hasil survey kependudukan Nasional menyebutkan sebanyak 3 dari 10 ibu yang bekerja di lapangan memiliki anak berusia di bawah 2 tahun. Jumlah ini terlihat dari adanya peningkatan jumlah keterlibatan peran nenek sebagai orang tua pengganti yang mengasuh anak (Tusianti, 2016).

Berdasarkan data tersebut, terlihat bahwa saat ini semakin banyak perempuan yang memilih untuk bekerja. Banyak faktor yang dapat mendukung ibu untuk ikut serta mencari nafkah diantaranya agar memperoleh penghasilan tambahan bagi keluarga, aktualisasi diri dan adanya tuntutan kehidupan keluarga bahkan masyarakat (Fridani, 2018). Keputusan ini tentunya akan memberikan berbagai macam dampak terhadap kehidupan perempuan khususnya bagi yang sudah menjadi ibu. Sosok ibu yang seharusnya menjadi contoh utama dan pertama bagi anak serta selalu berada di dekat anak tergantikan oleh sosok pengganti yang bertanggung jawab dalam mengasuh anak di rumah saat ibu bekerja. Hal ini berdampak kepada perbedaan pengasuhan yang diberikan oleh ibu dan nenek kepada anak. Perbedaan pengasuhan dapat dilihat dalam penanaman nilai-nilai dan norma seperti sikap kemandirian dan melatih keterampilan sosial pada anak. Namun, keberadaan ibu yang bekerja membuat ibu membutuhkan bantuan pihak ketiga untuk meengasuh anak (Halim, Jhonson, \& Perova, 2017). Seorang pengasuh dalam hal ini adalah babysitter yang bekerja dalam waktu tidak dapat diprediksi lamanya. Keadaan ini akan menyulitkan anak untuk bertindak konsisten dalam bersikap baik dalam hal kemandirian maupun mengembangkan keterampilan sosial seperti bekerjasama dan berkomunikasi.

Seperti yang terjadi pada sebuah keluarga di Rawamangun, Jakarta Timur yang memiliki anak usia 6 tahun berinisial $\mathrm{K}$ dan memiliki orang tua bekerja. Setiap hari ketika pulang sekolah dan saat orang tua $\mathrm{K}$ bekerja, $\mathrm{K}$ diasuh oleh pengasuh sekaligus merangkap asisten rumah tangga. Dalam periode tertentu nenek $\mathrm{K}$ yang berasal dari Bogor sering berkunjung ke rumah dan mengambil peran untuk mengasuh K. Situasi ini memberikan gambaran pola baru dalam pengasuhan dan berdampak kepada kemandirian dan keterampilan sosial K. Berdasarkan hal tersebut, penelitian ini bertujuan untuk mengkaji secara mendalam bentuk-bentuk kemandirian dan keterampilan sosial yang muncul pada anak uisa 5-6 tahun yang memiliki kedua orang tua bekerja di Jakarta, mengkaji faktor-faktor penghambat kemandirian dan keterampilan sosial, dan melihat gambaran pola asuh pada keuarga dual career family di Jakarta yang memilki anak usia 5-6 tahun.

Berdasarkan hasil penelitian dari Santoso dan Fahrinnia (2018), keadaan dual career family yang menempatkan posisi ibu bekerja sehinggan melibatkan orang ketiga dalam pengasuhan anak. Namun ibu merasa kuang puas mengenai hasil yang diperoleh dari pengasuhan. Sebagai contoh, Bibi sebagai pengganti ibu hanya berperan pada kebutuhan fisik saja seperti mengganti popok, memberi makan, dan memandikan anak. Tetapi anak bermain sendiri saat sepulang sekolah tanpa adanya keterlibatan bibi. Kontrol yang diberikan bibi juga terasa kurang, yang hanya terlihat bibi lebih memberikan fasilitas handphone dan game tanpa memberikan pengawasan dan waktu yang diberikan tidak terbatas. Hal ini akan berpengaruh terhadap keterampilan sosial anak. Perbedaan yang terdapat pada penelitian Santoso, Fahrinnia dan yang peneliti lakukan adalah peneliti melihat kemandirian dan keterampilan anak sedangkan penelitian dari Santoso dan Fahrinnia melihat dampak yang timbul akibat pengasuhan pihak ketiga yaitu bibi dalam keluarga dengan keadaan kedua orang tua bekerja.

Selanjutnya, penelitian yang dilakukan oleh Gürbüz dan Kiran (2018) menunjukkan hasil keterampilan sosial anak lebih tinggi apabila diasuh oleh ibu yang demokratis dan 
permisif jika dibandingkan dengan pengasuhan dari ibu yang otoriter. Hasil penelitian dari Gürbüz dan Kiran (2018) diperoleh data bahwa ibu yang bekerja lebih cenderung memberikan pola asuh yang protektif jika dibadingkan dengan ibu yang tidak bekerja. Namun Gürbüz dan Kiran (2018) berpendapat bahwa pola asuh yang diberikan oleh ibu memiliki banyak faktor seperti tingkat stress ibu dan latar belakang sosial ekonomi ibu. Sementara itu, penelitian yang dilakukan peneliti berdasarkan dengan data awal yang didapat bahwa ibu dari subjek penelitian melarang subjek untuk bermain di luar rumah bersama anak sebaya dan untuk bermain di rumah kakek dan nenek yang lokasinya tidak jauh dari rumah K. Data dari penelitian yang dilakukan oleh Gürbüz dan Kiran (2018) adalah ibu dari 354 anak yang berada di Turki dengan status bekerja dan tidak bekerja. Sedangkan penelitian yang dilakukan oleh peneliti mengambil satu subjek penelitian dengan kondisi ibu bekerja.

Mengacu kepada beberapa penelitian terdahulu yang telah dilakukan Santoso dan Fahrinnia (2018), serta Gürbüz dan Kiran (2018) terlihat keadaan keluarga, pola asuh, dan lingkungan memberikan pengaruh terhadap perkembangan dan pertumbuhan anak. Berdasarkan beberapa penelitian tersebut, belum terlihat adanya penelitian yang menunjukkan secara terperinci pasangan dual career family memberikan pengasuhan kepada anak. Beberapa penelitian sebelumnya juga belum menunjukkan hasil mengenai pekembangan kemandirian dan keterampilan sosial anak dalam pegasuhan keluarga dual career family secara utuh. Selain itu, penelitian terdahulu yang telah dilakukan Santoso dan Fahrinnia (2018), serta Gürbüz dan Kiran (2018) hanya terbatas hubungan antara ibu dan anak, anak dan sekolah tetapi peran ayah belum teridentifikasi dengan baik. Perbedaan selanjutnya terletak pada adalah jenis penelitian yang dipilih. Peneliti menggunakan jenis penelitian kualitatif dengan tipe one case study bertujuan untuk melihat secara menyeluruh bentukbentuk kemandirian dan keterampilan sosial anak, faktor yang berpengaruh terhadap kemandirian dan keterampilan sosial anak, serta pola pengasuhan yang terjadi dalam keluarga dual career family. Sementara penelitian sebelumnya yang dilakukan oleh Santoso dan Fahrinnia (2018), Gürbüz dan Kiran (2018) menggunakan jenis penelitian kuantitatif dengan banyak sampel sehingga fenomena-fenomena yang muncul saat dilapangan belum terkeskpos dengan baik. Berdasarkan hal tersebut, urgensi dan tujuan penelitian ini dilakukan untuk mejabarkan secara mendalam kepada orang tua bekerja yang memiliki anak usia dini mengenai kelebihan dan kekurangan dalam menjalankan dual career family.

\section{METODOLOGI}

Penelitian ini merupakan penelitan kualitatif jenis studi kasus yang menggunakan metode Miles and Hubberman. Tujuan menggunakan jenis penelitian ini karena adanya keinginan peneliti untuk mengkaji secara mendalam gambaran kasus yang dialami oleh K yakni perkembangan kemandirian dan keterampilan sosial yang terhambat serta faktor- faktor pendukung sehingga kasus terjadi. Penelitian ini dilakukan selama bulan Desember 2019 hingga Februari 2020 pada satu keluarga di kecamatan Pulogadung Jakarta Timur. Penelitian ini memiliki enam informan yaitu K ( subjek penelitian berusia 6 tahun), orang tua $\mathrm{K}$, pengasuh, guru, dan nenek yang dipilih menggunakan purposive sampling. Hal ini dilakukan untuk mendapatkan informasi yang mendalam mengenai perkembangan kemandirian dan keterampilan sosial $\mathrm{K}$.

Peneliti sendiri merupakan instrument dalam penelitian ini sesuai dengan posisi dalam penelitian kualitatif yang dikenal sebagai human instrument. Peneliti mengamati keseharian dan interaksi yang dilakukan $\mathrm{K}$ selama berada di rumah dan di sekolah untuk memperoleh data yang berkaitan dengan kemanidrian dan keterampilan sosial. Peneliti juga mengamati penerapan pola asuh yang diberikan oleh orang tua, pengasuh, nenek, dan guru di sekolah sehingga menghasilkan perbedaan pola asuh dan dampaknya keada kemandirian dan keterampilan sosial anak. Metode pengumpulan data dilakukan dengan cara pengamatan, wawancara yang mendalam, serta pengumpulan dokumentasi yang dikumpulkan dengan cara triangulasi. Tujuan dari triangulasi yaitu untuk menguji tingkat validitas yang dilakukan 
selama penelitian berlangsung. Sementara itu, pengamatan langsung dilakukan kepada subjek penelitian untuk memperoleh data bentuk-bentuk kemandirian dan keterampilan sosial, faktor-faktor yang mempengaruhi kemandirian dan keterampilan sosial, serta pola asuh yang diterapkan dalam dual career family. Wawancara yang mendalam dilakukan kepada orang tua, pengasuh dan juga guru kelas seputar kehidupan anak. Data yang diperoleh selanjutnya dianalaisis dengan cara mengorganisasikan data, mensortir data mana yang diperlukan mana yang tidak, mensintesiskan data, menentukan pola, serta menentukan hasil penelitian (Moleong, 2018). Proses ini dilakukan oleh peneliti sejak sebelum memasuki lapangan sampai kegiatan penelitian selesai. Selanjutnya, data dianalisis menggunakan model Miles and Huberman melalui beberapa tahap yaitu reduksi data; mencari pola dengan memberikan kode pada tiap skema yang muncul dari hasil pengamatan dan wawancara yang telah dilakukan. Penyajian data; data ditampilkan dalam bentuk naratif secara terperinci dan jelas. Selanjutnya merupakan tahap penarikan kesimpulan; memastikan kebenaran dari informasi yang telah didapat selama penelitian dengan cara menyelaraskan data tersebut dengan teori dan referensi yang ada (Sugiyono, 2010).

Berikut adalah ilustrasi dalam analisis data menggunakan model Miles and Hubberman:

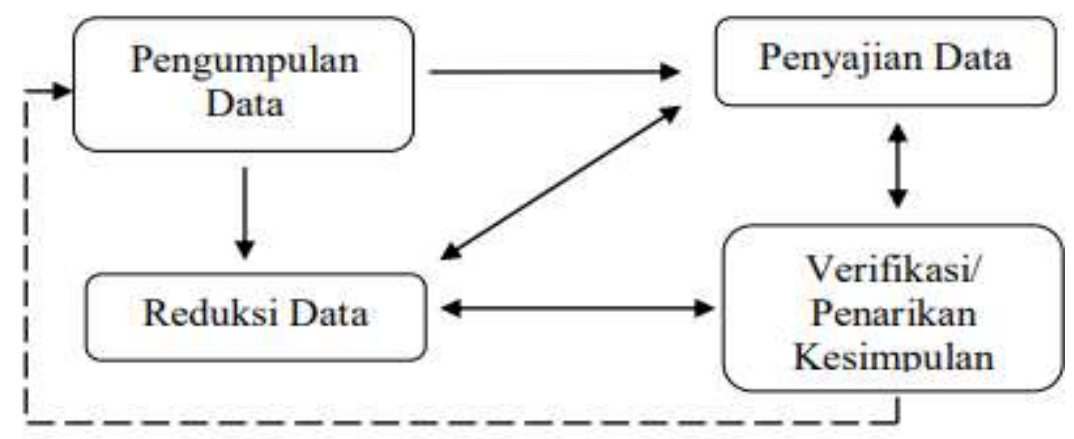

Gambar 1. Analisis data studi kasus model Miles and Hubberman (Lexi \& M.A., 2010)

\section{HASIL DAN PEMBAHASAN}

\section{Gambaran Umum Tentang Subjek dan Latar Penelitian}

$\mathrm{K}$ tinggal bersama orang tua kandung di rumahnya yang berlokasi di daerah Pulogadung, Jakarta Timur. Ayah K berusia 32 tahun dan ibu K berusia 31 tahun, keduanya memiliki pendidikan terakhir yaitu S2. Ayah K bekerja sebagai karyawan BUMN sedangkan Ibu K bekerja sebagai auditor di sebuah bank. Berdasarkan temuan di lapangan, diperoleh informasi bahwa ayah K bekerja sebagai karyawan BUMN dan Ibu K merupakan auditor di sebuah bank. Orang tua K bekerja setiap hari Senin sampai Jumat dan menghabiskan waktu sebanyak 13 jam berada di luar rumah. Selama orang tua K bekerja, pengasuhan K dilakukan oleh asisten rumah tangga dengan inisial mbak M. Mbak M selalu membantu kebutuhan $\mathrm{K}$ mulai dari menyiapkan dan memberikan makanan, mengenakan pakaian, kaos kaki, hingga membantu saat $\mathrm{K}$ di toilet. Mbak $\mathrm{M}$ terlihat memberikan $\mathrm{K}$ kebebasan untuk bertindak saat di rumah dan memberikan sedikit pengawasan. Sebagai contoh, saat $\mathrm{K}$ menonton televisi, mbak $\mathrm{M}$ mengerjakan pekerjaan rumah di dapur. Begitu juga saat $\mathrm{K}$ membaca buku, mbak $\mathrm{M}$ tidak turut serta mendampingi K. K merupakan anak berusia 6 tahun yang memiliki ayah dan ibu bekerja.

Saat malam hari, ayah dan ibu K tiba di rumah sekitar pukul 19.30 WIB. Ayah kurang terlibat aktifitas bersama K. Hal ini terlihat keterlibatan hanya sebatas menjadi imam sholat Isya saat di rumah. Selebihnya, ayah fokus kepada permainan game di HP hingga larut malam. Sementara itu, ibu lebih sering menghabiskan waktu bersama K dan adik saat malam hari. Seperti yag terlihat Ketika ibu sedang bercakap-cakap dengan $\mathrm{K}$, "teteh gimana tadi di 
sekolah? Selesai nggak ngerjain tugas dari Miss nya?". Dari percakapan tersebut ibu hanya peduli sebatas aktifitas akademik saja.

\section{Bentuk-bentuk Kemandirian Anak Usia 5-6 Tahun}

Bentuk-bentuk kemandirian yang muncul dalam kehidupan sehari-hari dapat dilihat ketika $\mathrm{K}$ bangun tidur, makan, menggunakan toilet, berpakaian, dan mengerjakan tugas akademik baik di sekolah maupun di rumah. Anak masih membutuhkan bantuan oleh orang dewasa seperti pengasuh, nenek dan ibu saat melakukan kegiatan yang berkaitan dengan partical life skill. Hal ini di dukung oleh ibu yang kurang memberikan stimulus terhadap kemandirian $\mathrm{K}$. Hal tersebut dapat dilihat saat $\mathrm{K}$ sedang makan dan lupa mengambil minum, ibu langsung berteriak, "Mbak, tolong refill minumannya teteh ini udah mau habis." Hal serupa juga terjadi ketika K akan buang air ke toilet, ibu langsung merespon dengan meminta mbak M untuk membantu K, "mbak tolong bantu itu teteh mau pipis buruan mbak." Anak diketahui baru membiasakan untuk tidak menggunakan pampers saat berada di sekolah sejak masuk kelas TK B. Oleh sebab itu, anak masih belum bisa untuk mengontrol saat ingin buang air kecil yang berujung kepada anak anak buang air kecil di celana (ngompol). Hal ini diketahui dari wawancara terhadap guru K yakni Miss S, " Kalau K mau pee atau pup masih harus ditemani aunty, dia belum berani ke toilet sendirian. Tapi masih mendingan sih udah mau buang air ke toilet karena baru sebulanan ini $\mathrm{K}$ lepas pampers biasanya ke sekolah masih pakai pampers." Untuk melihat secara rinci perbedaan bentuk kemandirian anak yang muncul dapat terlihat dalam tabel 1.

\section{Tabel 1 Perbedaan bentuk kemandirian K saat di rumah dan sekolah}

\begin{tabular}{llll}
\hline No & \multicolumn{1}{c}{ Aktivitas K saat di rumah } & No & \multicolumn{1}{c}{ Aktivitas K saat di sekolah } \\
\hline & $\begin{array}{l}\text { Partical life ( makan, minum, mandi, } \\
\text { buang air, berpakaian, memasang, dan } \\
\text { melepas sepatu ) masih membutuhkan } \\
\text { bantuan dan pelayanan dari pengasuh. }\end{array}$ & 1 & $\begin{array}{l}\text { Partical life ( makan, minum, buang air, } \\
\text { memasang, dan melepas sepatu) dapat } \\
\text { dilakukan dengan inisiatif sendiri sesuai } \\
\text { jadwal dan tanpa bantuan. } \\
\text { Guru masih menamani dan membantu anak } \\
\text { apabila ingin ke toilet. }\end{array}$ \\
& $\begin{array}{l}\text { Tugas akademik ( membaca, } \\
\text { Mengerjakan PR, mewarnai); dilakukan } \\
\text { dengan inisiatif sendiri. } \\
\text { Menghabiskan waktu dengan menonton } \\
\text { televisi }\end{array}$ & 2 & $\begin{array}{l}\text { Tugas akademik ( belajar); memiliki rasa } \\
\text { ingin tahu yang baik, dapat mengerjakan } \\
\text { perintah dengan baik, dan menyelesaikan } \\
\text { tugas yang diberikan. }\end{array}$ \\
\hline
\end{tabular}

Kemandirian merupakan keterampilan yang perlu dilatih sedini mungkin. Seperti yang dikatakan oleh Côté-lecaldare et al.,( 2016 ) bahwa mengembangkan kemandirian pada anak-bukan dengan cara memaksakan dan mengharapkan perilaku positif pada anak. Anak perlu diberikan kepercayaan untuk dapat mengembangkan dirinya sendiri disertai penerapan disiplin dengan pengawasan orang dewasa yang berada di sekitar anak. Oleh sebab itu, orang tua hendaknya memberikan anak ruang dan kesempatan untuk belajar menjadi anak yang mandiri (Safitri, Ahmad, \& Saleh, 2018) Pada penelitian ini, orang tua belum memberikan anak ruang dan kepercayaan untuk dapat mengerjakan aktivitas yang berkaitan dengan life skills di rumah. Hal ini terlihat dari orang tua yang memberikan tugas pengasuh untuk selalu membantu anak dalam menyelesaikan tugasnya seperti membantu saat anak makan, minum, berpakaian, mandi dan buang air.

\section{Bentuk-bentuk Keterampilan Sosial Anak Usia 5-6 Tahun}

Bentuk keterampilan sosial anak yang dianalisis adalah kemampuan kerjasama dan komunikasi. Setelah penelitian dilakukan, diperoleh data bahwa orang tua masih belum menjalin kerjasama kepada anak saat melakukan kegiatan di rumah. Orang tua juga melarang 
anak untuk keluar pagar rumah saat bermain dan menjalin pertemanan dengan anak yang sebaya di sekitar rumah. Menurut ibu hal ini dikarenakan ayah dan ibu tidak ingin anaknya terbiasa berada di luar rumah. Hal ini tergambar dari wawancara kepada ibu, "saya tidak mau anak saya kebiasaan main di luar tante. Mumpung masih kecil harus dibiasakan berada di rumah. Toh semua fasilitas juga udah kita lengkapin dan $\mathrm{K}$ juga sepertinya sudah cukup untuk bermain di sekolah." Sementara itu saat di sekolah, guru berusaha untuk mendorong anak agar dapat bekerjasama dan berkomunikasi dengan baik dengan cara mendesain pembelajaran yang melibatkan anak secara aktif dalam kegiatan kelompok kecil. Apabila saat merasa tidak nyaman maka anak langsung menarik diri. Bentuk keterampilan anak yang muncul disajikan dalam tabel 2.

Tabel 2 : Bentuk kerjasama dan komunikasi K

\begin{tabular}{|c|c|c|c|}
\hline No & Kerjasama & No & Komunikasi \\
\hline 1 & $\begin{array}{l}\text { K hanya mau berteman dengan } S \\
\text { dan J saja saat di sekolah. }\end{array}$ & 1 & $\begin{array}{l}\text { K belum bisa mengekspresikan emosi dengan baik } \\
\text { seperti kecewa, marah, dan menangis. }\end{array}$ \\
\hline 2 & $\begin{array}{l}\text { K belum mengerti konsep } \\
\text { berbagi saat bersama teman di } \\
\text { sekolah. }\end{array}$ & 2 & $\begin{array}{l}\text { K tidak berani untuk memulai pembicaraan } \\
\text { dengan teman saat di kelas }\end{array}$ \\
\hline 3 & $\begin{array}{l}\text { K masih belum bisa menerima } \\
\text { keputusan yang diambil dalam } \\
\text { kelompok kecil saat berada di } \\
\text { kelas. }\end{array}$ & 3 & $\begin{array}{l}\text { K belum mengerti arturan dari sebuah permainan } \\
\text { yang dirancang oleh teman-temannya sehingga } \\
\text { sering terjadi misunderstanding dan berakibat } \\
\text { kepada K sering tidak diajak main bersama. }\end{array}$ \\
\hline
\end{tabular}

Keterampilan sosial anak usia dini dapat terlihat melalui aktifitas berikut : (a) anak ikut bermain dan menjalin kontak dengan teman kelompok, (b) adanya aktifitas komunikasi dan interaksi dengan teman sebaya, (c) memiliki empati sehingga anak dapat melihat dari sudut pandang anak lain, (d) anak dapat berbagi mainan dengan anak lain, (e) anak dapat menghargai keberadaan anak-anak lain, (f) anak mampu mengkespresikan kemarahan dan kekecewaan dengan baik (Beaty, 2013; Meggit, 2013).

Hasil penelitian ini menunjukkan bahwa keteramapilan sosial anak belum bekrembang dengan baik sesuai tahapan usianya. Sejalan dengan pendapat Arends (2012) yakni keterampilan sosial dipengaruhi oleh kondisi individu serta pengalaman interaksi dengan lingkungan. Kondisi ini mendorong guru untuk selalu memberikan motivasi kepada anak agar dapat bermain dan berbagi bersama teman-teman yang lain. Sejalan dengan pendapat Liduma ( 2017) bahwa, salah satu peran guru taman kanak-kanak adalah menciptakan lingkungan kelas yang kondusif karena banyaknya anak-anak yang bersifat heterogen sehingga anak-anak tersebut dapat bergaul dengan baik.

\section{Faktor-faktor Yang Mempengaruhi Kemandirian dan Keterampilan Sosial}

Kemandirian dan keterampilan sosial yang dimiliki oleh anak disebabkan berbagai macam faktor diantaranya adalah motivasi dari diri anak dan sekitar serta kontrol lingkungan. Motivasi dalam diri anak untuk mandiri sudah terlihat apabila anak berada di sekolah. Hal ini juga didukung oleh program sekolah dan guru yang selalu memberikan stimulus pada anak agar dapat tumbuh mandiri seperti makan sendiri, memasang dan melepas sepatu sendiri, tidak memakai pampers di sekolah dan mampu menggunakan toilet sendiri. Guru bertugas memantau dan akan memberikan bantuan secara langsung apabila anak merasa kesulitan dan butuh bantuan dalam mengerjakan sesuatu yang dirasa anak kurang mampu. Sementara itu motivasi diri yang dimiliki anak saat di rumah untuk berperilaku mandiri kurang diberikan stimulus oleh orang tua. Orang tua selalu melibatkan dan meminta pengasuh untuk membantu anak dalam menyelesaikan tugas yang berkaitan dengan keseharian anak yang seharusnya bisa anak selesaikan sendiri. 
Hal tersebut juga berlaku terhadap keterampilan sosial anak yang berkaitan dengan komunikasi, kerjasama, dan tanggung jawab. Saat disekolah, guru berusaha merancang pembelajaran untuk menstimulus keterampilan sosial anak. Adapun cara-cara yang dilakukan guru antara lain merancang tempat duduk agar anak dapat duduk bersama anakanak yang berbeda setiap hari. Hal ini disebabkan karena pada awal memasuki TK B, anak hanya ingin berada di dekat $S$ dan $J$ saja. Guru juga berusaha meminta anak untuk membagikan alat tulis kepada teman-temannya dan bertanggung jawab untuk mengumpulkannya kembali saat pelajaran berakhir. Guru juga sering menggunakan metode proyek untuk mendukung cooperative learning dalam proses pembelajaran di sekolah agar anak mampu bekerjasama dengan baik.

\section{Pola Pengasuhan Dalam Dual Career Family}

Situasi kedua orang tua K yang memiliki pekerjaan di luar rumah memberikan pilihan kepada orang tua untuk mempekerjakan pengasuh yang akan membantu dalam memberikan pengasuhan kepada $\mathrm{K}$ saat di rumah. Hal ini dikarenakan waktu yang dimiliki oleh orang tua saat di rumah sangat terbatas. Keterlibatan ayah dalam pengasuhan di rumah terlihat ketika ayah berperan sebagai guru mengaji dan imam sholat. Ayah juga bertugas untuk mengantar $\mathrm{K}$ ke sekolah apabila supir tidak bisa masuk kerja. Sementara itu, ibu lebih terlihat dalam memastikan kebutuhan dan keperluan $\mathrm{K}$ terpenuhi. Ibu juga selalu memantau aktivitas yang dilakukan $\mathrm{K}$ setiap hari dengan menanyakan kepada pengasuh saat malam hari. Dalam pengasuhan, orang tua mengontrol penuh keadaan anak dengan memberikan aturan-aturan yang tegas seperti anak dilarang bermain di luar pagar bersama anak-anak sebaya di sekitar lingkungan rumah, orang tua melarang anak untuk pergi bermain ke rumah kakek dan nenek serta anak juga dilarang mandi pagi sebelum pukul 07.00 WIB dengan alasan untuk kebaikan anak. pemberian hukuman berupa kurungan di kamar selalu diberikan untuk mengancam anak. Berdasarkan hal tersebut pola pengasuhan yang digunakan orang tua $\mathrm{K}$ adalah pola asuh otoriter. Pola asuh otoriter terlihat dari adanya kontrol kuat dan aturan kaku yang harus dipatuhi sehingga mengakibatkan anak menjadi takut untuk memulai pembicaraan dan bercerita apabila terjadi sesuatu kepada anak.

Sementara itu, apabila nenek berkunjung kerumah, nenek terlihat mengabaikan beberapa aturan yang telah dibuat oleh keluarga $\mathrm{K}$ seperti nenek akan mengajak $\mathrm{K}$ mandi sebelum pukul 07.00 WIB dan memberikan kesempatan K untuk mandi sendiri tetapi dengan batasan waktu yang ditentukan. Nenek juga memberikan kesempatan K unuk makan sendiri apabila menu makanannya bukan ikan. Selain itu, nenek juga selalu memastikan K untuk rutin tidur siang setiap hari dan mengajak K untuk berjalan- jalan di sekitar lingkungan rumah pada sore hari. Kehadiran nenek di rumah $\mathrm{K}$ memberikan gambaran pola asuh yang berbeda dari yang orang tua $\mathrm{K}$ terapkan. Pola pengasuhan yang diterapkan nenek adalah pola asuh otoritatif. Hal ini terlihat ketika nenek menerima perilaku $\mathrm{K}$ tetapi tetap memberikan batasanbatasan kepada K. Nenek tidak pernah memberikan hukuman kepada K tetapi lebih memberikan pengertian sebab dan akibat kepada $\mathrm{K}$ jika $\mathrm{K}$ tidak ingin melakukan sesuatu. Perbedaan pola asuh yang diterapkan orang tua dan nenek disajikan pada tabel 3.

\section{Tabel 3. Bentuk pola asuh orang tua $\mathrm{K}$}

\begin{tabular}{clcl}
\hline No. & \multicolumn{1}{c}{ Pola asuh orang tua } & No & \multicolumn{1}{c}{ Pola asuh nenek } \\
\hline 1 & $\begin{array}{l}\text { Sedikit menghabiskan waktu } \\
\text { bersama K karena bekerja }\end{array}$ & 1 & $\begin{array}{l}\text { Jika nenek sedang tinggal bersama K di } \\
\text { rumah, maka nenek akan menghabiskan } \\
\text { waktu 24 jam bersama K }\end{array}$ \\
2 & $\begin{array}{l}\text { Melimpahkan tugas pengasuhan } \\
\text { secara full kepada pengasuh }\end{array}$ & 2 & $\begin{array}{l}\text { Nenek terlibat dalam pengasuhan K } \\
\text { Adanya kontrol berupa beberapa } \\
\text { aturan yang dibuat oleh orang tua }\end{array}$ \\
\end{tabular}


4 Adanya hukuman apabila K melanggar aturan

Ayah kurang mengajak komunikasi kepada $\mathrm{K}$
4 Membiasakan anak bangun subuh dan mandi sebelum jam 06.00 WIB.

$5 \quad$ Nenek memberikan kepercayaan dan kesempatan kepada K untuk mencoba melakukan banyak kegiatan.

6 Terjalinnya hubungan yang hangat antara nenek dan $\mathrm{K}$

\section{Pembahasan}

Kemandirian berasal dari kata diri yang menunjukkan suatu sikap dari diri individu. Einon berpendapat bahwa kemandirian bukanlah sebuah kondisi yang telah ada, namun kemandirian timbul melalui sebuah proses dan adanya ruang untuk anak melakukan yang hal yang diinginkan (Ayllón, Moyano, Mozano, \& Cava, 2019). Selain itu, untuk mencapai suatu sikap mandiri yang baik, anak membutuhkan dukungan dan penguatan dari orangorang sekitar. Saat penelitian dilakukan anak masih berada pada tahap pelatihan toilet training. Toilet training dapat dilakukan saat anak memasuki usia 1 sampai 3 tahun (Andresni et al., 2020). Hal ini dikarenakan memasuki usia tersebut, syaraf-syaraf dan otot anak sudah siap yang ditandai dengan anak sudah lancar berjalan dan berlari dengan seimbang. Konsitensi, kepercayaan, dan dukungan yang diberikan kepada anak juga merupakan faktor penting dalam kesuksesan toilet training dan juga untuk melatih kemanidiran anak (Kiddoo, 2012).

Sejalan dengan hal tersebut, perkembangan keterampilan sosial yang baik membutuhkan dukungan dari keluarga dan dapat dimulai sejak dini. Keterampilan sosial yang dikembangkan dengan baik pada masa kanak-kanak akan berpengaruh terhadap interaksi sosial di masa depan. Hal ini sejalan dengan pendapat Laugen, Jacobsen, Rieffe, \& Wichstrøm, ( 2017, p. 6) bahwa, keterampilan sosial seperti mengetahui cara berkompromi atau meminta bantuan, merupakan komponen penting anak dalam pengembangan kompetensi sosial.

Fenomena dual career family membuat orang tua kekurangan waktu bersama anak sehingga kurang terlibat dalam pengasuhan. Selain itu, masalah yang muncul dalam dual career family seperti ekonomi, dan timbulnya kesulitan saat menyelesaikan pekerjaan rumah (Januarti, 2010; Rizkillah, Sunarti, \& Herawati., 2015). Orang tua menghabiskan waktu lebih dari 11 jam beraktivitas di luar rumah dan saat tiba di rumah, energi yang ada telah berkurang sehingga akan mempengaruhi kualitas pengasuhan. Meskipun demikian, bukan menjadi alasan bagi orang tua untuk melimpahkan pengasuhan sepenuhnya kepada pengasuh. Sejalan dengan yang dikatakan oleh Lang (2014) bahwa dalam keluarga berkarir ganda pengasuhan intensif tetap diberikan oleh orang tua. Meskipun dengan waktu yang terbatas, orang tua tetap harus mencurahkan perhatian dalam rangka menstimulus anak agar mencapai semua tugas perkembangan termasuk kemandirian dan keterampilan sosial.

Setiap keluarga dapat memilih pola pengasuhan yang sesuai dengan kebutuhan keluarga. Menurut Baumrind pola asuh adalah suatu cara yang diterapkan oleh orang tua dalam membesarkan anaknya (Agustina \& Appulembang, 2017). Pola pengasuhan yang digunakan akan menentukan sikap orang tua terhadap anak dan sebaliknya. Baumrind menjabarkan bahwa terdapat tiga bentuk pola asuh, diantaranya adalah pola asuh otoriter (kontrol, kaku, adanya hukuman), pola asuh permisif ( penerimaan, kurang kontrol), dan pola asuh otoritatif (demokratis, fleksibel, hukuman sederhana apabila anak melanggar (Bibi et al., 2013; Theresya et al., 2018).

Dalam penelitian ini adanya kontrol ketat yang diberikan orang tua terlihat dari banyaknya peraturan yang harus anak taati. Berdasarkan gambaran tersebut, pola asuh yang dilakukan oleh orang tua adalah pola asuh otoriter karena adanya kontrol dan batasan. Hal ini bertentangan dengan pendapat Jannah (2017) dalam pengasuhan, orang tua seharusnya tidak memaksakan kehendaknya dan harus mengetahui kebutuhan dasar anak serta disesuaikan dengan tahapan perkembangannya. Sementara itu, yang dimaksud kebutuhan dasar anak pada usia dini adalah untuk belajar menjelajahi lingkungan dengan cara bermain (UNESCO, 2018). 
Keterbatasan dalam penelitian ini terletak pada subjek penelitian yaitu hanya satu keluarga dan lama penelitian yang dilakukan hanya dua bulan. Untuk mengkaji lebih dalam mengenai pengasuhan dual career family, dibutuhkan banyak subjek penelitian sehingga menemukan pola pengasuhan yang beragam.

\section{SIMPULAN}

Fenomena dual career family adalah keadaan keluarga ketika sepasang suami dan istri sama-sama bekerja. Hal ini akan berdampak pada pengasuhan anak usia dini sehingga menuntut orang tua untuk membagi tugas pengasuhan dengan orang ketiga yaitu pengasuh. Hasil menunjukkan adanya perbedaan pola asuh yang diterapkan antara orang tua, pengasuh dan guru di sekolah. Orang tua menerapkan pola pengasuhan otoriter dan nenek menerapkan pola asuh otoritatif. Pola asuh yang diberikan oleh orang tua, nenek, dan pengasuh berpengaruh terhadap kemandirian dan keterampilan sosial anak.

\section{UCAPAN TERIMA KASIH}

Peneliti haturkan terima kasih kepada Lara Fridani, PhD dan Dr. Asep Supena, M.Psi selaku pembimbing dalam penulisan ini. Selanjutnya, terima kasih juga diberikan kepada semua pihak yang terlibat dalam pelaksanaan penelitian ini dan kepada Jurnal Obsesi yang sudah memberikan kesempatan untuk memproses artikel ini.

\section{DAFTAR PUSTAKA}

Agustina, A., \& Appulembang, Y. A. (2017). Pengaruh Pola Asuh terhadap Kualitas Hidup Siswa Pelaku Tawuran. Jurnal Muara Ilmu Sosial, Humaniora, Dan Seni, 1(1), 210. https:// doi.org/10.24912/jmishumsen.v1i1.351

Andresni, H., Zahtamal, Z., Septiani, W., Mitra, M., \& Lita, L. (2020). Effectiveness Of Toilet Training Education On Mother's Behavior And Toddler Age Toilet Training Ability (18-36 Months). Jurnal Kesehatan Komunitas, 5(2), 49-55. https:// doi.org/10.25311/keskom.Vol5.Iss2.288

Avivah Wittenberg. (2020). The Rise, Resilience, And Challenges Of 2- Career Couples. FORBES. https://www.forbes.com/sites/avivahwittenbergcox/2020/10/13/therise-resilience-and-challenges-of-2-career-couples/?sh=4dabea6fbabe

Ayllón, E., Moyano, N., Lozano, A., \& Cava, M. J. (2019). Parents' willingness and perception of children's autonomy as predictors of greater independent mobility to school. International Journal of Environmental Research and Public Health, 16(5). https:// doi.org/10.3390/ijerph16050732

Beaty, J. J. (2013). Observasi Perkembangan Anak Usia Dini (Edisi Ketujuh) (7th ed.). Kencana Prenamedia Group.

Bibi, F., Chaudhry, A. G., Awan, E. A., \& Tariq, B. (2013). Contribution of Parenting Style in life domain of Children. IOSR Journal of Humanities and Social Science, 12(2), 91-95. https:// doi.org/10.9790/0837-1229195

Côté-Lecaldare, M., Joussemet, M., \& Dufour, S. (2016). How to Support Toddlers' Autonomy: A Qualitative Study With Child Care Educators. Early Education and Development, 27(6), 822-840. https:/ / doi.org/10.1080/10409289.2016.1148482

Fridani, L. (2018). Ibuku Sibuk Antara Tuntutan dan Pilihan. Penerbit Lentera Ilmu Cendikia.

Green, C. J. (2019). Young children's spatial autonomy in their home environment and a forest setting. Journal of Artificial Intelligence and Soft Computing Research, 9(1), 65-85. https://doi.org/10.2478/iped-2018-0004

Gülay Ogelman, H., Güngör, H., Körükçü, Ö., \& Erten Sarkaya, H. (2018). Examination of the relationship between technology use of 5-6 year-old children and their social skills and social status*. Early Child Development and Care, 188(2), 168-182. https://doi.org/10.1080/03004430.2016.1208190 
Gürbüz, E., \& Kiran, B. (2018). Research of Social Skills of Children Who Attend to Kindergarten According to the Attitudes of Their Mothers. Journal of Education and Training Studies, 6(3), 95. https:// doi.org/10.11114/jets.v6i3.2831

Halim, D., Johnson, H., \& Perova, E. (2017). Dapatkah Layanan Pengasuhan Anak Meningkatkan Hasil Bursa Kerja Perempuan di Indonesia ? World Bank, 2017(1), 4-7.

Hanifah, U. N. (2020). Tipologi Pengasuhan Ibu Bekerja, Kemandirian Dan Kecerdasan Adversity Anak. Institut Agama Islam Negeri Salatiga. http://erepository.perpus.iainsalatiga.ac.id/8251/

Hesti. (2017). Jumlah Tenaga Kerja Perempuan di Indonesia. Independen.

Jannah, M. M. (2017). Dentifikasi Pola Asuh Orang Tua Di Taman Kanak-Kanak Aba Jogokaryan Yogyakarta. Jurnal Pendidikan Anak Usia Dini Edisi 6, 1-8.

Januarti, N. E. (2010). Problematika Keluarga dengan Pola Karir Ganda (Studi Kasus di Wilayah Mangir, Sendangsari, Pajangan, Bantul, Yogyakarta). Artikel, 4(2), 19-54.

Kiddoo, D. A. (2012). Toilet training children: When to start and how to train. In CMAJ (Vol. 184, Issue 5, pp. 511-512). https://doi.org/10.1503/cmaj.110830

Kuhn, S. D. (2017). Building Peer Independence among Children. Masters of Arts in Education Action Research Papers, 1-38.

Lang, S. N., Schoppe-Sullivan, S. J., Kotila, L. E., Feng, X., Kamp Dush, C. M., \& Johnson, S. C. (2014). Relations Between Fathers' and Mothers' Infant Engagement Patterns in DualEarner Families and Toddler Competence. Journal of Family Issues, 35(8), 1107-1127. https://doi.org/10.1177/0192513X14522243

Laugen, N. J., Jacobsen, K. H., Rieffe, C., \& Wichstrøm, L. (2017). Social skills in preschool children with unilateral and mild bilateral hearing loss. Deafness and Education International, 19(2), 54-62. https:// doi.org/10.1080/14643154.2017.1344366

Lexi, J., \& M.A., M. (2010). Metodologi Penelitian Kualitatif. In Metodologi Penelitian Kualitatif. Rake Sarasin, 54-68. https://scholar.google.com/citations?user=OB3eJYAAAAJ\&hl=en

Liduma, A. (2017). Collaboration in the Kindergarten as a Pedagogical Means for Developing Positive Attitudes. International Dialogues on Education, 4(1), 1001-1106. https:// www.ide-journal.org/article/2017-volume-4-number-1-collaboration-in-thekindergarten-as-a-pedagogical-means-for-developing-positive-attitudes/

Meggit, C. (2013). Memahami Perkembangan Anak (Tim Indeks (ed.); Seri Belaj). PT. Indeks. https://doi.org/10.1145/2505515.2507827

Papalia, D. E., \& Feldman, R. D. (2014). Menyelami perkembangan manusia edisi 12 buku 1. Jakarta: Salemba Humanika. https:// doi.org/ISBN/ISSN. 978-602-8555-79-1

Richard I Arends. (1976). Learning to teach. Educational Studies in Mathematics, 7(3), 332-350. https://doi.org/10.1007/BF00553920

Rizkillah, R., Sunarti, E., \& Herawati, T. (2015). Kualitas Perkawinan dan Lingkungan Pengasuhan pada Keluarga dengan Suami Istri Bekerja. Jurnal Ilmu Keluarga Dan Konsumen, 8(1), 10-19. https:/ / doi.org/10.24156/jikk.2015.8.1.10

Safitri, M. E., Ahmad, K. I., \& Saleh, M. (2018). Development of Child Independence Through Model Picture and Picture, Examples Non Examples Model and Practical Method Directly Activities of Learning Practical Life in Group B Kasih Ibu Kindergarten, Banjarmasin, Indonesia. European Journal of Education Studies, 5(7), 64-80. https://doi.org/10.5281/zenodo.1494229

Santoso, S. T. P., \& Fahrinnia, V. (2018). Mom Worked: Patterns of Parenting and Attachment by Children. Atlantic, 244(Ecpe), 189-192. https:// doi.org/10.2991/ecpe-18.2018.42

Santrock, J. W. (2015). Life-Span Development (15th ed.). McGraw-Hill International Edition. Sugiyono. (2010). Metode Penelitian Pendidikan Pendekatan Kuantitatif, Kualitatif, dan R\&D. Bandung: Alfabeta. 
Theresya, J., Latifah, M., \& Hernawati, N. (2018). The Effect of Parenting Style, Self-Efficacy, and Self Regulated Learning on Adolescents' Academic Achievement. Journal of Child Development Studies, 3(1), 28. https:// doi.org/10.29244/jcds.3.1.28-43

Tusianti, E. (2016). Peran Ganda Ibu Masa Kini dalam Angka oleh Ema Tusianti Halaman all - Kompasiana. Kompasiana.Com. https://www.kompasiana.com/tusianti/585c5d5c43afbd27359f62cd/peran-gandaibu-masa-kini-dalam-angka?page=all

UNESCO. (2018). Learning Through Play. https://doi.org/10.1111/j.14683156.1976.tb00253.x

Yolanda, E. (2020). Professional and Pedagogical Competence of Early Childhood Education Teachers in Millenial Era. Advances in Social Science, Education and Humanities Research, 449(19), 66-70. https:// doi.org/10.2991/assehr.k.200715.013

Zhang, M. (2019). Modeling Grace and Courtesy in a Montessori Classroom and its Influence on Children 's Social Behavior. Master of Arts in Education Action Research Paperaster of Arts in Education Action Research Paper, 1-35. https://sophia.stkate.edu/maed/333 